\title{
IMPLEMENTASI MEDIA PEMBELAJARAN BERBASIS ANDROID PADA MATERI KEANEKARAGAMAN HAYATI DI SMAN 08 KOTA BENGKULU
}

\author{
Eva Fawziah $^{1 *}$, Ariefa Primairyani ${ }^{1}$, Irdam Idrus ${ }^{1}$ \\ ${ }^{1}$ Program Studi Pendidikan Biologi, Fakultas Keguruan dan Ilmu Pendidikan, Universitas Bengkulu \\ email: evafawziah71@gmail.com
}

\begin{abstract}
Abstrak
Penelitian ini bertujuan untuk mengetahui ada atau tidaknya peningkatan hasil belajar peserta didik setelah menggunakan media pembelajaran berbasis android bambu expert system pada materi keanekaragaman hayati di SMA Negeri 08 Kota Bengkulu. Penelitian ini dilakukan di SMAN 08 Kota Bengkulu, yaitu pada kelas X MIA 3 (kelas kontrol) dan X MIA 4 (kelas eksperimen). Keanekaragaman hayati merupakan salah satu kompetensi dasar kelompok pengetahuan di kelas X. Metode penelitian yang digunakan adalah Eksperimen quasi (eksperimen semu) dengan desain penelitian pretets-posttes control group design. Instrumen yang digunakan merupakan tes objektif pilihan ganda sebanyak 15 butir soal. Teknik analisis data dilakukan dengan pengujian hipotesis yang menggunakan uji-t, pada taraf signifikansi $5 \%(\alpha=0,05)$ dan $\mathrm{db}=28$ didapat $_{\text {tabel }}(2,048)$ dan $\mathrm{t}_{\text {hitung }}$ $(2,259)$, terbukti bahwa hipotesis alternatif $\left(H_{1}\right)$ yang diajukan diterima karena $t_{\text {hitung }}>t_{\text {tabel }}(2,259>2,048)$, dapat disimpulkan bahwa ada pengaruh penggunaan media pembelajaran bambu expert system terhadap peningkatan hasil belajar peserta didik pada materi keanekaragaman hayati.
\end{abstract}

Kata kunci: Media pembelajaran, android, bambu expert system, Keanekaragaman hayati, Hasil belajar

\begin{abstract}
This study aims to determine whether or not the improvement of learning outcomes of learners after using instructional media android based bamboo expert system on biodiversity material in SMA Negeri 08 Bengkulu city. This research was conducted at SMAN 08 Bengkulu city, that is in class X MIPA 3 (control class) and X MIPA 4 (experiment class). Biodiversity is one of the basic competencies of knowledge groups in class $X$. The research method used is quasi experiments with pretets-posttes control group design research design. The instrument used is a multiple choice objective test of 15 items. Technical data analysis is done by testing the hypothesis using t-test, at $5 \%$ significance level $(\alpha=0,05)$ and $\mathrm{db}=28$ obtained t table $(2.048)$ and titung $(2,259)$, proved that alternative hypothesis $(\mathrm{H} 1)$ because tcount $>\mathrm{t}$ table $(2,259>2.048)$, it can be concluded that there is influence of using bamboo expert system learning media to increase learners' learning outcomes on biodiversity material.
\end{abstract}

Keywords: Learning media, android, bamboo expert system, Biodiversity, Learning result

\section{PENDAHULUAN}

Proses pembelajaran merupakan suatu kegiatan yang dilaksanakan secara terencana dan terorganisir. Kenyataannya proses pembelajaran di sekolah masih monoton hanya menggunakan buku-buku yang tersedia, belum memanfaatkan kemajuan teknologi yang ada. Agar proses pembelajaran tersebut dapat berjalan dengan baik, selain unsur sarana dan prasarana, penggunaan model dan media pembelajaran juga perlu diperhatikan. Pendidikan masa kini mengacu pada pendidikan dengan multi dimensi yang mengedepankan pendekatan IPTEK. Kemajuan teknologi informasi dan komunikasi telah merubah gaya hidup manusia, baik dalam bekerja, bersosialisasi, bermain maupun belajar. Oleh karena itu guru dan peserta didik dituntut agar memiliki kemampuan pembelajaran pada era globalisasi sekarang ini. Guru dan peserta didik dituntut mampu menggunakan alat-alat yang disediakan oleh sekolah. Guru sekurangkurangnya dapat menggunakan alat yang murah dan efisien, meskipun sederhana namun merupakan keharusan dalam upaya mencapai tujuan pengajaran yang diharapkan. Untuk itu guru harus memiliki pengetahuan dan pemahaman yang cukup tentang media pembelajaran (Permendiknas, 2007).

Media pembelajaran merupakan salah satu komponen sumber belajar yang penting, suatu alat atau perantara yang berguna untuk memudahkan proses belajar mengajar antara guru dan peserta didik. Menurut Syaiful,dkk (2014) media sebagai alat bantu dalam proses belajar mengajar adalah suatu kenyataan yang tidak dapat dipungkiri.

Berdasarkan wawancara dengan guru bidang studi Biologi SMAN 08 Kota Bengkulu pada tanggal 19 Desember 2017 terdapat empat kendala dalam pembelajaran biologi yang diungkapkan: 1) peserta didik cenderung malas jika sudah berhubungan dengan hafalan. Menurut keterangan guru, materi yang sifatnya menghafal dan banyak konsep yang harus dipahami membuat peserta didik merasa kesulitan; 2) minat baca rendah, ketika dihadapkan dengan materi biologi yang sifatnya pemahaman konsep, peserta didik sangat sulit ketika disuruh membaca; 3) buku teks biologi yang disediakan oleh sekolah masih kurang untuk menunjang kebutuhan peserta didik, kurangnya buku teks biologi menjadi 
keterbatasan saat peserta didik ditugaskan mencari referensi lain tentang materi yang sedang dipelajari; 4) masih jarang peserta didik yang membawa laptop, meskipun jaringan wi-fi sudah tersedia di sekolah. Peserta didik lebih memilih membawa android (smartphone) daripada laptop karena lebih ringan.

Hasil penelitian mengenai media pembelajaran berbasis android telah dikembangkan oleh Primairyani, dkk (2016) mengenai materi keanekaragaman hayati, yang terfokus mengenai tumbuhan bambu yakni Bambu Expert System. Media pembelajaran berbasis android Bambu Expert System ini merupakan sebuah website pembelajaran. Website pembelajaran ini dapat dijadikan sebagai media pembelajaran bagi peserta didik, karena di dalam website ini terdapat materi, dan informasi yang lengkap mengenai keanekaragaman tanaman bambu yang disertai penjelasan mengenai klasifikasi, morfologi, habitan dan segala sesuatu mengenai keanekaragaman bambu.

Pembelajaran biologi pada materi keanekaragaman hayati salah satunya dapat dilakukan dengan mengamati jenis-jenis tanaman bambu yang ada di lingkungan sekitar. Tanaman bambu merupakan jenis tanaman yang dapat dimanfaatkan untuk kebutuhan manusia seperti bahan bangunan rumah, kursi, dan lain sebagainnya. Jenis tanaman bambu sangat banyak, ada bambu kuning, bambu hitam, bambu cina, dan lain-lain. Dari banyak jenis tersebut, dapat dikembangkan menjadi sebuah website media pembelajaran berbasis android yang sesuai dengan materi keanekaragaman hayati yaitu keanekaragaman tingkat jenis. Hal ini sesuai dengan KD 3.1 Mendeskripsikan konsep keanekaragaman gen, jenis, ekosistem, melalui kegiatan pengamatan Kemendikbud (2016).

Tujuan penelitian ini adalah untuk mengetahui ada atau tidaknya pengaruh media pembelajaran berbasis android bambu expert system terhadap hasil belajar biologi siswa kelas $X$ pada materi keanekaragaman hayati di SMAN 08 Kota Bengkulu.

\section{METODE}

Metode penelitian yang digunakan dalam penelitian ini adalah kuasi eksperimen. Metode eksperimen kuasi dilakukan karena peneliti tidak dapat melakukan eksperimen yang sesungguhnya. Desain yang digunakan dalam penelitian ini yaitu pretets-posttes control group design, yang dapat dilihat pada Tabel 1.

\section{Tabel 1. Desain Penelitian}

\begin{tabular}{ccc}
\hline Pretes & Perlakuan & posttes \\
\hline O1 & $\mathrm{X}$ & $\mathrm{O} 2$ \\
$\mathrm{O} 3$ & $\mathrm{O}$ & \\
\hline
\end{tabular}

Keterangan:

O1 dan 02 : kelompok kontrol

O3 dan 04 : kelompok eksperimen

$\mathrm{X}$ : perlakuan

Subjek dalam penelitian ini adalah siswa kelas X di SMAN 08 Kota Bengkulu tahun ajaran 2018/2019. Subjek penelitian dipilih sebanyak dua kelas yakni X MIPA 3 dan X MIPA 4, yang dijadikan sebagai kelas kontrol dan kelas eksperimen. Adapun kelas kontrol yakni kelas X MIPA 3 dan kelas eksperimen X MIPA 4. Kelas eksperimen diberikan media pembelajaran berbasis android Bambu Expert System.

Teknik pengumpulan data yang digunakan dalam penelitian ini adalah tes. Tes digunakan untuk memperoleh data mengenai ketuntasan hasil belajar siswa. Bentuk instrumennya adalah lembar tes yang disusun berdasarkan tujuan pembelajaran khusus yang meliputi aspek kognitif yang disesuaikan dengan tuntutan pengajaran pada siswa SMA. Teknik pengambilan data dilakukan dua kali dengan instrumen pengukuran berupa soal pilihan ganda yang terdiri dari 20 soal, dengan pensekoran jika benar diberi skor 1 dan jika salah diberi skor 0 . Tes yang diberikan sebelum perlakuan disebut tes awal (pretest), dan tes yang diberikan setelah perlakuan disebut tes akhir (posttest).

Lembar tes yang digunakan di validasi secara empiris terlebih dahulu untuk meningkatkan kesahihannya. Adapun hal yang harus dilakukan dalam melakukan validasi lembar instrumen tes adalah sebagi berikut:

1) Uji validitas

Untuk menguji validitas soal digunakan rumus korelasi produk moment sebagai berikut:

$r_{x y}=\frac{\Sigma x y}{\sqrt{(\Sigma x 2)(\Sigma y 2)}}$

(Arikunto,2013).

Untuk menlihat apakah soal dikatakan valid, dilihat dari kriteria penafsiran indeks validitas yang dapat dilihat pada Tabel 2 .

Tabel 2. Interpretasi Koefisien Korelasi Nilai r. 


\begin{tabular}{cc}
\hline Interval Koefisien & Tingkat Hubungan \\
\hline $0.800-1.00$ & Sangat tinggi \\
$0.600-0.800$ & Tinggi \\
$0.400-0.600$ & Cukup \\
$0.200-0.400$ & Rendah \\
$0.00-0.200$ & Sangat rendah \\
\hline
\end{tabular}

\section{2) Menguji reliabilitas soal}

Reliabilitas alat penilaian adalah ketepatan alat tersebut dalam menilai apa yang dinilainya. Uji ini dilakukan dengan teknik split half (belah dua) dari Spearman Brown dengan rumus:

$r 11=2(r 1 / 21 / 2) 1+r 1 / 2 \quad 1 / 2$

(Arikunto,2013).

Untuk menganalisa data tes hasil belajar dilakukan langkah sebagai berikut, setelah datadata diperoleh maka sebelumnya terlebih dahulu dilakukan uji prasyarat analisis yaitu uji normalitas dan uji homogenitas.

1) Uji Normalitas, uji ini dilakukan dengan uji Liliefor, dengan langkah sebagai berikut:

a. tentukan nilai Z, dari tiap-tiap data

b. Tentukan peluang dari $F(Z i)$. Kolom $\mathrm{F}(\mathrm{Zi})$ adalah nilai probabilitas dari $\mathrm{Zi}$ dapat dilihat dengan menggunakan Ms.Exel (=normdist (sorot Xi)

c. Menentukan s(zi) dengan rumus S(zi) $=$ Fkum $: \mathrm{N}$

d. Menghitung nilai liliefors hitung dengan rumus $\mathrm{Lh}=[\mathrm{F}(\mathrm{zi})-\mathrm{S}(\mathrm{zi})]$

e. Untuk mengetahui apakah sample berasal dari populasi yang berdistribusi normal maka nilai Lhitung dikonsultasikan dengan tabel nilai kritis $L$ dengan taraf signifikansi alpha $=0,05$, kriteria pengujian populasi ini dianggap berdistribusi normal jika harga Lhitung < Ltabel (angka kritis)

2) Uji homogenitas

Uji homogenitas dilakukan untuk mengetahui apakah kedua kelompok sampel berasal dari populasi yang sama(homogen) atau tidak. Uji homogenitas yang digunakan adalah uji $\mathrm{F}$ (Fisher).

Telah ditentukan kriteria pengujian $\mathrm{H}_{0}$ yaitu:

a. Jika $\mathrm{F}_{\text {hitung }}<\mathrm{F}_{\text {tabel, }}$ maka $\mathrm{H}_{0}$ diterima (data memiliki varians homogen).

b. Jika $F_{\text {hitung }}>\mathrm{F}_{\text {tabel, }}$ maka $\mathrm{H}_{0}$ ditolak (data tidak memiliki varians homogen)
3) Uji hipotesis

Jika uji normalitas dan uji homogenitas telah terpenuhi maka dapat dilakukan pengujian hipotesis. Pengujian hipotesis yang digunakan dalam penelitian ini adalah dengan menggunakan rumus t-tes. Dengan taraf signifikansi $5 \%(\alpha=0,05)$

$$
t=\frac{\bar{x} 1-\bar{x} 2}{\sqrt[S g a b]{\frac{1}{n_{1}}+\frac{1}{n_{2}}}}
$$

(Arikunto,2013).

Telah ditentukan kriteria pengujian :

a) Jika $t_{\text {hitung }}<t_{\text {tabel }}$ maka $\mathrm{H}_{0}$ diterima dan $\mathrm{H}_{1}$ ditolak

b) Jika $t_{\text {hitung }}>t_{\text {tabel }}$ maka $H_{0}$ ditolak dan $\mathrm{H}_{1}$ diterima.

\section{HASIL DAN PEMBAHASAN}

Berdasarkan hasil penelitian yang telah dilakukan, data hasil penelitian berupa data prettest dan posttest, dapat dilihat pada Gambar 1.

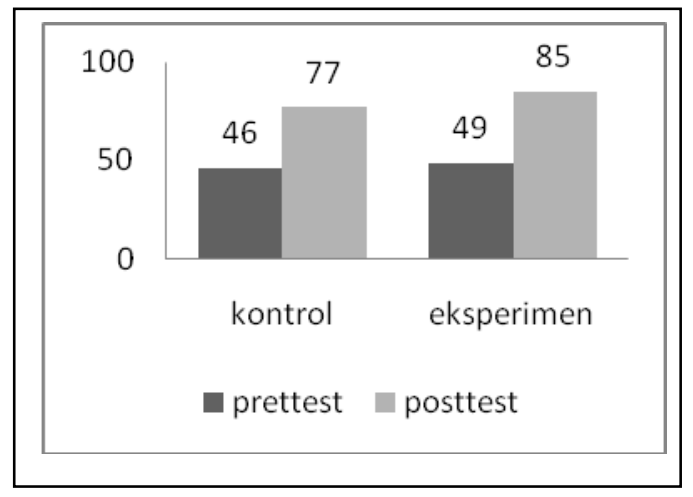

\section{Gambar 1. Perbandingan Rata-Rata Nilai Pretest Kelas Kontrol Dan Kelas Eksperimen}

Data prettest dan posttest yang didapat diolah dengan uji analisis normalitas, homogenitas, dan hipotesis. Hasil Analisis dari ketiga uji tersebut sebagai berikut:

1) Uji Normalitas

Berikut ini adalah rekapitulasi hasil pengujian normalitas data pretest dan data posttest pada kelas eksperimen dan kelas kontrol, yang ditunjukkan pada Tabel 3. 
Tabel 3 Rekapitulasi Hasil Uji Normalitas (Uji Liliefors) Data Pretest Dan Posttest Kelas Kontrol Dan Kelas Eksperimen

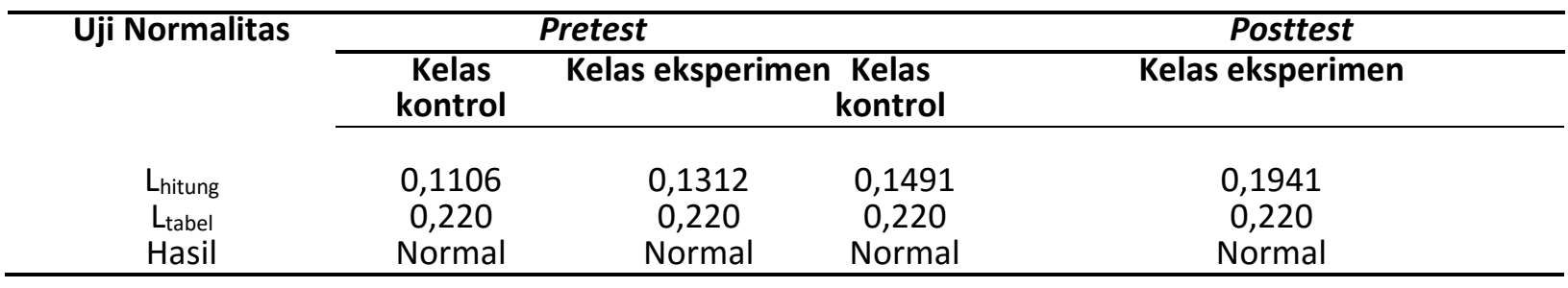

Berdasarkan Tabel 3 dapat dilihat bahwa keempat data berdistribusi normal, baik data pretest maupun data posttest. Nilai L hitung data pretest kelas kontrol maupun kelas eksperimen dan data posttest kelaskontrol maupun kelas eksperimen Lhitung < Ltabel maka semua data terdistribusi normal.

2) Uji Homogenitas

Uji homogenitas dilakukan untuk mengetahui apakah sebaran data dari masingmasing kelas memiliki varians yang homogen atau tidak. Kedua kelas dinyatakan homogen apabila memenuhi kriteria Fhitung < Ftabel, yang berarti kedua varians homogen. Berikut ini adalah rekapitulasi hasil pengujian homogenitas kelas eksperimen dan kelas kontrol, yang ditunjukkan pada Tabel 4.

Tabel 4. Rekapitulasi Hasil Uji Homogenitas Data Pretest Dan Data Posttest Kelas Kontrol Dan Kelas Eksperimen

\begin{tabular}{|c|c|c|}
\hline Uji & Pretest & Posttest \\
\hline Homogenitas & $\begin{array}{cc}\text { Kelas } & \text { Kelas } \\
\text { kontrol eksperimen }\end{array}$ & $\begin{array}{cc}\text { Kelas } & \text { Kelas } \\
\text { kontrol eksperimen }\end{array}$ \\
\hline Nilai Ftabel & 2,48 & 2,48 \\
\hline Hasil & Homogen & Homogen \\
\hline
\end{tabular}

Berdasarkan Tabel 4 dapat dilihat bahwa data pretest dan posttest kedua kelas memiliki varians yang homogen. Data pretest untuk kelas eksperimen dan kelas kontrol untuk $d b$ penyebut 14 dan db pembilang 14 pada Ftabel taraf signifikansi $5 \%(\alpha=0,05)$ adalah 2,48, dengan Fhitung sebesar 1,21. Hal ini menunjukkan bahwa data tersebut memiliki varians homogen dan berasal dari populasi yang homogen karena memenuhi kriteria Fhitung < Ftabel $(1,21<2,48)$.
Sedangkan data posttest untuk kelas eksperimen dan kelas kontrol untuk $\mathrm{db}$ penyebut 14 dan db pembilang 14 pada Ftabel taraf signifikan $5 \%$ adalah 2,48, dengan Fhitung sebesar 1,25. Hal ini menunjukkan bahwa data tersebut memiliki varians homogen dan berasal dari populasi yang homogen karena memenuhi kriteria Fhitung $<$ Ftabel $(1,25<2,48)$.

\section{3) Hasil Uji Hipotesis}

Berdasarkan hasil uji prasyarat analisis statistik terhadap data dari kedua kelas di atas, diperoleh bahwa data kedua kelas berdistribusi normal dan memiliki varians yang homogen. Oleh karena itu, uji hipotesis dilakukan dengan menggunakan uji-t. Hasil perhitungan uji hipotesis pretest dapat dilihat pada Tabel 5 .

Tabel 5. Hasil Perhitungan Uji Hipotesis Pretest

\begin{tabular}{cccc}
\hline \multirow{2}{*}{ Uji Hipotesis } & \multicolumn{2}{c}{ Nilai Rata-rata } \\
\cline { 3 - 4 } Nilai thitung & $\begin{array}{c}\text { Kelas } \\
\text { kilai }\end{array}$ & $\begin{array}{c}\text { Kelas } \\
\text { kontrol }\end{array}$ & $\begin{array}{c}\text { eksperimen } \\
t_{\text {tabel }}\end{array}$ \\
0,88 & 2,048 & 46 & 49 \\
\hline
\end{tabular}

Dari Tabel 5 dapat dilihat nilai rata-rata kelas eksperimen $\left(X 1^{\bar{X}_{1}}\right)$ adalah 49 dan nilai rata- rata kelas kontrol $\left(X 2^{X_{2}}\right.$ ) adalah 46 . Nilai deviasi standar gabungan (dsg) adalah 9,64.

Berdasarkan hasil uji hipotesis pretest diperoleh $t_{\text {hitung }}<t_{\text {tabel. }}$ Untuk $d b=\left(n_{1}+n_{2}\right)-2=$ $(15+15)-2=28, t_{\text {tabel }}$ pada taraf signifikansi $5 \%(\alpha=0,05)$ adalah 2,048. Karena $t_{\text {hitung }}<t_{\text {tabel }}$ $(0,88<2,048)$, maka $\mathrm{H}_{0}$ diterima dan $\mathrm{H}_{1}$ ditolak. Sehingga dapat dikatakan tidak ada perbedaan nyata nilai rata-rata antara kelas kontrol dengan kelas eksperimen. Untuk hasil perhitungan uji hipotesis Posttest dapat dilihat pada Tabel 6. 
Tabel 6. Hasil Perhitungan Uji Hipotesis posttest

\begin{tabular}{|c|c|c|c|}
\hline \multicolumn{2}{|c|}{ Uji Hipotesis } & \multicolumn{2}{|c|}{ Nilai Rata-rata } \\
\hline & & Kelas & Kelas \\
\hline Nilai $t_{\text {hitung }}$ & Nilai & kontrol & eksperimen \\
\hline $\mathbf{0 , 8 8}$ & $\begin{array}{l}\mathrm{t}_{\text {tabel }} \\
2,048\end{array}$ & 77 & 85 \\
\hline
\end{tabular}

Keterangan: $\mathrm{H}_{1}$ diterima jika $\mathrm{t}_{\text {hitung }}>\mathrm{t}_{\text {tabel }}$

Nilai deviasi standar gabungan (dsg) adalah 9,84. Berdasarkan hasil uji hipotesis posttest diperoleh thitung $>t_{\text {tabel. }}$. Untuk $\mathrm{db}=\left(\mathrm{n}_{1}+\right.$ $\left.\mathrm{n}_{2}\right)-2=(15+15)-2=28, \mathrm{t}_{\text {tabel }}$ pada taraf signifikansi $5 \%(\alpha=0,05)$ adalah 2,048 . Karena $t_{\text {hitung }}>t_{\text {tabel }}(2,259>2,048)$, maka $\mathrm{H}_{0}$ ditolak dan $\mathrm{H}_{1}$ diterima. Sehingga dapat dikatakan ada perbedaan nyata nilai rata-rata antara kelas kontrol dengan kelas eksperimen.

Penelitian ini merupakan penelitian yang dilakukan untuk mengetahui pengaruh hasil belajar antara peserta didik yang diajarkan dengan menggunakan media pembelajaran berbasis android bambu expert system sebagai kelas eksperimen dengan peserta didik yang tidak menggunakan media pembelajaran berbasis android bambu expert system sebagai kelas kontrol. Untuk mengetahui hasil belajar peserta didik dilakukan dengan memberikan tes, tes yang diberikan berupa (pretest dan posttest). Pretest dan Posttest dilakukan pada kedua kelas, yaitu kelas kontrol (X MIPA 3) dan kelas eksperimen (X MIPA 4) dengan jumlah masing-masing 15 peserta didik. Data pretest adalah data tes kognitif untuk mengetahui pengetahuan awal peserta didik mengenai materi keanekaragaman hayati. Data hasil posttest adalah data yang diambil setelah proses pelaksanaan pembelajaran.

Dari data hasil posttest yang telah dilakukan, diketahui ada perbedaan nyata. Hal ini sesuai dengan Nuroifah dan Bachtiar Syaiful Bachri (2015), yang menyatakan bahwa media pembelajaran berbasis android dapat meningkatkan hasil belajar peserta didik.

Hasil belajar yang diperoleh peserta didik dipengaruhi oleh beberapa faktor, yaitu pertama faktor guru. Guru sangat berperan penting dalam proses belajar peserta didik karena peserta didik akan mengikuti perintah atau instruksi yang diberikan guru, maka dari itu guru dalam proses pembelajaran perlu melakukan kegiatan yang dapat menuntut respon peserta didik seperti kalimat tanya maupun kalimat perintah agar peserta didik dapat aktif dalam mengikuti proses pembelajaran. Pada saat proses pembelajaran berlangsung guru melibatkan peserta didik dengan cara mengamati langsung objek kemudian hasil pengamatan dibandingkan dengan literatur yang relevan. Menurut Dimyati (2013), bahwa guru memberikan kesempatan kepada peserta didik untuk mengumpulkan informasi yang relevan dengan melakukan eksperimen dan membaca literatur. Sehingga peserta didik belajar aktif untuk menemukan sesuatu yang berhubungan dengan permasalahan yang dihadapi.

Kedua, faktor model dan metode pembelajaran. Pada proses pembelajaran digunakan model discovery learning dengan metode diskusi dan pengamatan. Metode dan model tersebut sangat cocok digunakan dalam pembelajaran biologi karena peserta didik terlibat langsug selama proses pembelajaran, peserta didik belajar menemukan konsep sendiri, sehingga peserta didik cepat memahami materi yang dipelajari. Hal ini sesuai dengan Hosnan (2014) yang menyatakan bahwa peserta didik akan lebih memahami materi jika mereka mampu terjun langsung dalam ke lapangan unuk mengamati dan menemukan konsep sendiri.

Ketiga faktor media pembelajaran, Pennggunaan media pembelajaran berbasis android bambu expert system ini dilakukan pada kegitan inti di dalam sintak model discovery learning. Media pembelajaran berbasis android bambu expert system yang digunakan dalam pembelajaran telah memberikan dampak yang baik karena rerata pencapaian hasil belajar tergolong cukup tinggi pada hasil posttest yang telah dilakukan. Pencapaian ini dikarenakan peserta didik dituntut untuk aktif dalam mencari informasi, materi yang terdapat dalam media pembelajaran. Dengan dilibatkannya peserta didik secara langsung dalam memahami materi membuat proses belajar tidak monoton dan lebih menarik. Karena didalam media pembelajaran berbasis android bambu expert system materi yang dibutuhkan oleh peserta didik terangkup apik dan menarik, dimana tidak hanya terdapat tulisan saja tetapi juga terdapat gambar-gambar yang membuat peserta didik seakan-akan melihat langsung objek yang sedang mereka pelajari walaupun mereka tidak terjun langsung ke lapangan.

Perbedaan hasil belajar antara kelas kontrol dan kelas eksperimen dapat dilihat dari hasil posttest peserta didik, seperti yang telah dijelaskan sebelumnya bahwa hasil posttest kelas eksperimen (85) berbeda nyata dibandingakn hasil posttest kelas kontrol (77). Hal ini dikarenakan proses pembelajaran pada kelas eksperimen yang menggunakan media 
pembelajaran berbasis android bambu expert system memiliki beberapa kelebihan diantaranya, susunan materi yang lebih runtun dan jelas, terdapat cover dan tampilan yang menarik, terdapat gambar-gambar yang mendukung materi, ringkas dan dapat dibuka dimana saja saat peserta didik ingin belajar, tidak membutuhkan tempat dan mudah digunakan dimana saja. Sehingga peserta didik lebih terarah dalam memahami materi dan pembelajaran menggunakan media pembelajaran berbasis android bambu expert system berpotensi untuk meningkatkan hasil belajar peserta didik. Hal ini sesuai dengan Sambono (2014) yang menyatakan bahwa media pembelajaran mobile learning ( $M$ learning) memiliki kelebihan dalam dapat dibuka dimana saja dan kapan saja yang memungkinkan peserta didik dapat belajar kapan saja saat mereka ingin, tanpa harus repot membawa buku dan alat tulis lainnya. Oleh karena itu dengan menggunakan media berbasis $m$-learning ini peserta didik mampu meningkatkan hasil belajarnya. Media pembelajaran berbasis android bambu expert system fokus pada permasalahan yang akan dipecahkan yaitu materi keanekaragaman hayati tanaman bambu. Contoh-contoh tanaman bambu yang terdapat di media pembelajaran ini yaitu keanekaragaman tanaman bambu yang terdapat di Bengkulu Utara.

Menurut Susilo (2017) media pembelajaran berbasis android sangat cocok digunakan dalam pembelajaran Biologi SMA. Media pembelajaran berbasis android memiliki sifat mobile yang mampu digunakan dimana saja sehingga mampu menarik minat peserta didik untuk belajar. Hal tersebut berdampak pada keefektifan pembelajaran sehingga dapat meningkatkan hasil belajar pada materi pembelajaran tersebut. Guru dapat merancang dan mengembang sendiri media tersebut sesuai dengan sarana dan kelengkapan yang dimilikinya serta keadaan sekolah. Pembelajaran biologi yang menggunakan media pembelajaran berbasis android dapat menyederhanakan materi dan membuat pembelajaran lebih menarik dan berinovasi.

Pada kelas kontrol, pembelajaran tanpa menggunakan media pembelajaran berbasis android bambu expert system membuat peserta didik cenderung lebih pasif karena tidak terdapat prosedur dan materi mengenai keanekaragaman hayati yang tertulis seperti yang ada di media pembelajaran berbasis android bambu expert system. Guru menjelaskan materi dengan metode ceramah dan mendeskripsikan tentang tanaman bambu hanya secara lisan, sehingga pembelajaran menjadi monoton dimana peserta didik hanya fokus mendengarkan guru saja. Peserta didik perlu mengingat dan mencatat penjelasan guru agar tidak lupa, sebagian peserta didik malas untuk mencatat dan hanya mendengarkan saja. Sehingga hal ini berdampak pada hasil posttest peserta didik kelas kontrol yang lebih rendah dibandingakan dengan hasil posttest peserta didik kelas eksperimen. Hal ini sesuai dengan Mahnun (2012) yang menyatakan bahwa materi pembelajaran yang sulit hendaklah memiliki media atau sarana dan prasana yang menarik peserta didik untuk belajar, sehingga dapat membantu peserta didik dan meningkatkan hasil belajar peserta didik.

\section{PENUTUP}

\section{Simpulan}

Berdasarkan hasil penelitian di SMA Negeri 08 Kota Bengkulu dan data hasil penelitian, pengolahan data, analisis dan pembahasan data, maka dapat disimpulkan bahwa terdapat pengaruh implementasi media pembelajaran berbasis android bambu expert system terhadap peningkatan hasil belajar peserta didik pada materi Keanekaragaman Hayati kelas X SMA Negeri 08 Kota Bengkulu, hal ini ditunjukkan dengan nilai rata-rata hasil posttest pada kedua kelas yang berbeda nyata yaitu, 77 pada kelas kontrol dan 85 pada kelas eksperimen.

\section{Saran}

Berdasarkan hasil penelitian yang dilakukan, maka saran yang dapat dikemukakan adalah:

1. Media pembelajaran berbasis android bambu expert system ini dapat dijadikan salah satu alternatif dalam memberikan materi pada proses pembelajaran

2. Terdapat kelemahan dalam media pembelajaran berbasis android bambu expert system seperti perlunya koneksi internet dalam menggunakannya, sehingga guru dan pihak sekolah harus mampu menyediakan koneksi internet bagi peserta didik untuk menggunakan media pembelajaran berbasis android ini.

3. Untuk memastikan pengaruh penggunaan media pembelajaran berbasis android bambu expert system terhadap peningkatan hasil belajar peserta didik, maka perlu dilakukan penelitian lebih lanjut dengan menggunakan media 
pembelajaran berbasis android bambu expert system pada tempat yang berbeda.

4. Bagi peneliti lain yang tertarik untuk menerapkan media pembelajaran berbasis android bambu expert system ini, maka disarankan untuk meninjau pembelajaran pada ranah afektif atau ranah psikomotorik.

\section{Daftar Pustaka}

Arikunto, Suharmi. 2013. Dasar-Dasar Evaluasi Pendidikan. Jakarta : Bumi Aksara

Dimyati, Mudjiono. 2013. Belajar dan Pembelajaran. Jakarta: Rineka Cipta

Hosnan. M. 2014. Pendekatan Sainstifik Dan Kontekstual Dalam Pembelajaran Abad 21. Bogor: Ghalia Indonesia

Kemendikbud.2016. Silabus Mata Pelajaran Sekolah Menengah Atas/Madrasah Aliyah (SMA/MA) Mata Pelajaran Biologi. Jakarta: Depkemendikbud

Mahnun, Nunu.2012. Media Pembelajaran (Kajian Terhadap Langkah-Langkah Pemilihan Media dan Implementasinya dalam Pembelajaran). Jurnal Pemikiran Islam Vol. 37, No. 1, JanuariJuni 2012. (https://ejournal.uinsuska.ac.id/index.php/anida/article/download/ 310/293\&rct/ diakses tanggal 19 April 2018)

Permendiknas. 2007. Standar Kualifikasi Akademik dan Kompetensi Guru. Jakarta: Depdiknas

Sambodo, Rizki Agung. 2014. Pengembangan Media Pembelajaran Mobile Learning (m-learning) Berbasis Android Untuk Siswa Kelas XSMA/MA. Disertai diterbitkan. Yogyakarta: Program Studi Pendidikan Biologi Universitas Negeri Sunan Kalijaga

Susilo, Muhammad Aji. 2017. Pengembangan Media Pembelajaran Berbasis Aplikasi Android Untuk Meningkatkan Hasil Belajar Kognitif Pada Pembelajaran Wheel Alignment Di SMK Negeri 2 Surakarta. Disertai diterbitkan. Semarang: Fakultas Teknis Universitas Negeri Semarang.

Syaiful Bahri, Djamarah., Zaim, Aswara. 2014. Strategi Belajar Mengajar. Jakarta : Rineka Cipta

Primairyani, Ariefa., Purwandi, Edina putri., Noperman, Feri., Sugraha, Famadhan. 2017. Bambu Expert System. Bengkulu : Universitas Bengkulu 